Article

\title{
Increasing Parameters of Diesel Engines by Their Transformation for Methanol Conversion Products
}

\author{
Sviatoslav Kryshtopa $^{1}$, Krzysztof Górski ${ }^{2} \mathbb{D}$, Rafał Longwic ${ }^{3, *} \mathbb{D}$, Ruslans Smigins ${ }^{4} \mathbb{C}_{\text {and }}$ Liudmyla Kryshtopa ${ }^{1}$ \\ 1 Department of Automobile Transport, Ivano-Frankivsk National Technical University of Oil and Gas, \\ Carpathians Street 15, 76019 Ivano-Frankivsk, Ukraine; trans@nung.edu.ua (S.K.); math@nung.edu.ua (L.K.) \\ 2 Faculty of Mechanical Engineering, Kazimierz Pulaski University of Technology and Humanities in Radom, \\ ul. Chrobrego 45, 26-200 Radom, Poland; krzysztof.gorski@uthrad.pl \\ 3 Faculty of Mechanical Engineering, Lublin University of Technology, ul. Nadbystrzycka 38D, \\ 20-618 Lublin, Poland \\ 4 Faculty of Engineering, Latvia University of Life Sciences and Technologies, J. Cakstes Blvd. 5, \\ LV-3001 Jelgava, Latvia; ruslans.smigins@llu.lv \\ * Correspondence: r.longwic@pollub.pl; Tel.: +48-81-538-42-68
}

check for updates

Citation: Kryshtopa, S.; Górski, K.; Longwic, R.; Smigins, R.; Kryshtopa, L. Increasing Parameters of Diesel Engines by Their Transformation for Methanol Conversion Products. Energies 2021, 14, 1710. https:// doi.org/10.3390/en14061710

\section{Academic Editors:}

Sławomir Wierzbicki,

Maciej Mikulski and Kamil Duda

Received: 10 February 2021

Accepted: 16 March 2021

Published: 19 March 2021

Publisher's Note: MDPI stays neutral with regard to jurisdictional claims in published maps and institutional affiliations.

Copyright: (c) 2021 by the authors. Licensee MDPI, Basel, Switzerland. This article is an open access article distributed under the terms and conditions of the Creative Commons Attribution (CC BY) license (https:// creativecommons.org/licenses/by/ $4.0 /)$.

\begin{abstract}
The work is aimed at solving the problem of converting existing diesel power drives to gas fuels, which are cheaper and more environmentally friendly alternatives to diesel fuel. Method of energy efficiency increasing of alternative fuels has been improved. Thermochemical essence of energy increasing of source fuel based on the provisions of thermodynamics is considered. Alternative methanol fuel has been chosen as initial product for conversion process and its cost, energy value, and temperature conditions have been taken into account. Calculations showed that the thermal effect from combustion of the converted mixture of $\mathrm{CO}$ and $\mathrm{H}_{2}$ exceeds the effect from combustion of the same amount of non-convertible methanol. Fuel energy and engine power were increased due to thermochemical regeneration of exhaust gas heat. An experimental setup was created to study the operation of a converted diesel engine on methanol conversion products. Experimental studies of power, economic, and environmental parameters of converted diesel engine for methanol conversion products were performed. Experimental studies have shown that conversion of diesel engines to work using methanol conversion products is technically reasonable. Fuel consumption reduction was accompanied by environmental performance improvement of the diesel engine working together with a thermochemical methanol conversion reactor. Formation of nitrogen oxides in the exhaust gases decreased in the range of $22-35 \%$, and carbon monoxide occurred in the range of $0-24 \%$ according to the crankshaft speed and loading on the engine. Conversion of diesel engines for methanol conversion products is very profitable, because the price of methanol is, on average, $10-20 \%$ of the cost of diesel fuel.
\end{abstract}

Keywords: diesel engine; nitrogen oxides; alternative fuel; methanol conversion; exhaust gases; heat utilization

\section{Introduction}

A significant part of automobiles and other types of transport use internal combustion engines with diesel power systems. This reason requires high fuel consumption of expensive diesel fuel with very significant parameters of exhaust gas toxicity; therefore, it is obvious the feasibility of switching to cheaper and more environmentally friendly alternative fuels [1]. Diesel engines have a long resource and there is no doubt that even after the complete cessation of the production of new diesel engines, the already produced diesel engines will be in operation for a long time. Therefore, the problem of converting existing diesel power drives to gas fuels, which are a cheaper and more environmentally friendly alternative to diesel fuel, deserves special attention [2]. 
Conversion of diesel engines to gas motor fuel is possible according to different schemes [3]. In general, the diesel engine can be converted to gas-diesel or monogas modes (Figure 1).

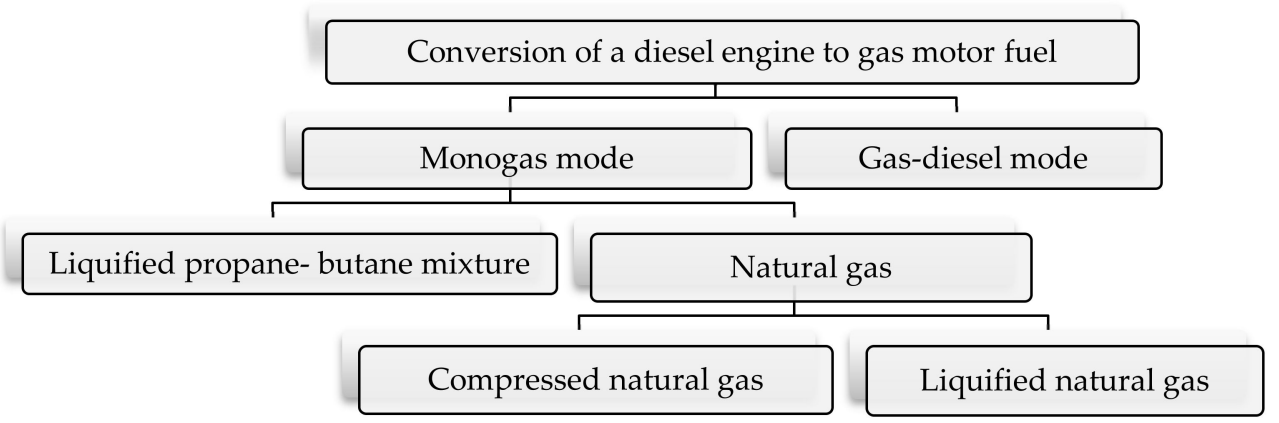

Figure 1. Directions of conversion of diesel engines to gas.

Technology of converting diesel engines to gas-diesel mode is already well-known and well-established at present, when both gas and diesel fuel supplies are used at the same time. In this case, an incendiary dose of diesel fuel is supplied to the gas fuel and it is positioned by the manufacturers of gas-diesel systems in the range of $25-40 \%$, and in real operating conditions reaches $50 \%$. This technology, along with certain advantages, has many disadvantages [4]; one of the main ones is the necessity to supply diesel fuel, but it impairs economic feasibility of conversion.

The second, less tested variant of converting diesel engines to gas motor fuel is a purely gas or monogas mode, where the converted diesel engines are additionally equipped with spark ignition systems. It is obvious that the supply of only pure gas or monogas mode is a more profitable alternative to the gas-diesel mode, given the absence of necessity to supply expensive diesel fuel. Diesel engine according to its design can be converted to work with gas cylinder equipment on both methane (compressed or liquefied) and propane-butane [5].

The economic advantages of converting diesel power drives of motor transport to monogas mode are related to the following [6]:

- monogas fuel is significantly cheaper than diesel fuel, and diesel fuel is not supplied at all;

- $\quad$ resource of cylinder-piston group of convertible engines, due to smoother increase in combustion pressures, increases by 1.3-1.5 times;

- frequency of replacement of motor oils and oil filters of monogas engines is approximately doubled, due to the reduction of carbon formation, the absence of process of washing the oil film, and reducing vacuum of engine oil;

Therefore, the conversion of diesel power drives of motor vehicles to monogas engines in terms of reducing the cost of fuel and lubricants and overhaul of engines is an urgent task.

Creation of monogas engines by the world's leading manufacturers of automobile engines and cars, which are already widely used in road transport, testifies to the significant prospects of converting diesel engines into gas with spark ignition [7]. Moreover, conversion of diesel engines is carried out both on liquefied propane-butane mixture and on compressed or liquefied natural gas. Well-known world concerns such as Frightliner, Sammins, Volvo, MAN, Mercedes, Scania, Iveco, and others are working in this direction, and they have already developed spark-ignition gas engines for commercial vehicles based on existing diesel engines.

Study of foreign and domestic developments experience shows that diesel engines, which are converted into gas, have high traction-dynamic and economic characteristics, and, according to environmental safety parameters, they are significantly superior to basic diesel engines [8]. 
Diesel engine conversion to monogas one requires major changes in the design of the base diesel [9], in contrast to the conversion of gasoline engines. Ignition of fuel in diesel engine is carried out by heating from compression, therefore standard diesel engine cannot work on gaseous fuel, as gas motor fuel has a significantly higher ignition temperature in comparison to diesel fuel (for example, diesel fuel: $300-330^{\circ} \mathrm{C}$, propane: $466{ }^{\circ} \mathrm{C}$ ), but it cannot be achieved with compression ratios used in diesel engines.

The second reason why a diesel engine will not be able to work on gas fuel is the phenomenon of detonation-it is an explosive combustion of fuel, which occurs at a high degree of compression. For diesel engines, degree of compression of the fuel-air mixture ranges from 14 to 22 and for a gas engine must have a degree of compression from 12 to 13 [10].

It should be noted that reduction of compression degree in converted into gas diesel engines is performed, as a rule, by boring the combustion chamber in the piston of the base diesel. However, experimental studies show that even minor changes in the shape of the combustion chambers in the pistons lead to significant changes in the processes of heat, mass, and gas exchange and combustion [11]. Therefore, optimization of the combustion chamber of a convertible engine requires serious calculation and experimental work to ensure high power, economic and environmental parameters of the engine.

In general, to convert diesel engines to gas fuel the following must be performed: to install gas cylinder equipment; to reduce the compression ratio of the base diesel engine; to assemble the ignition system; to configure the engine management system. It should be noted it is necessary to answer many questions of scientific, technical and commercial nature because there is only initial experience in conversion of diesel engines into alcohol ones [12,13].

It is necessary to choose the type of gaseous fuel taking into account conversion of chemical fuel energy into work. Conversion of chemical energy of any type of fuels into work in internal combustion engines is carried out in two stages: at the first stage, it is converted into heat; in the second stage, the heat is realized in work. There are the basic losses of fuel energy during these transformations. The efficiency of the internal combustion engine can be significantly increased by taking into account of such losses [14].

It is necessary to reduce losses of chemical energy of fuel in internal combustion engines at both stages of the transformation to increase efficiency of its usage. In existent engine construction, mainly different methods are used to reduce energy loss of fuel efficiency in the second stage of energy conversion [15].

In modern engines, temperature level of the working fluid is such one that its further increase causes a serious problem of providing the required thermal strength [16]. Therefore, increasing fuel efficiency in a heat engine by increasing the upper thermodynamic temperature of the working fluid in the cycle depends on the possibility of further increasing the heat resistance and heat resistance of structural materials of engine parts. These possibilities for most traditional materials are almost exhausted, it becomes obvious that this method becomes unpromising.

According to these conditions, it is advisable to develop a method to reduce irreversible losses in the first stage of conversion of chemical energy of fuel into heat. Moreover, implementation of this method should not be associated with an increase in the temperature level of the working fluid. In the case of internal combustion engines to ensure the preliminary endothermic stage of conversion as a starting convertible product, it is advisable to use such types of alternative fuels that have a conversion temperature below the average temperature of the exhaust gases [17]. Such fuels may include lower alcohols, alkanes, and simple ethers [18]. The choice of alternative fuel as a product for the conversion process is a compromise that takes into account the temperature conditions of the process, its energy value, formed during the processing of gases, and their cost $[19,20]$.

The most promising product for organization of conversion in the first place should include methyl alcohol (methanol) that, in world practice, has long been used as a cheap 
substitute for expensive traditional motor fuels (Table 1). For comparison, the average cost of diesel fuel in Europe [21] ranges from 1-1.6 Euro/liter (1.15-1.9 Euro/kg).

Table 1. Conversion temperature Tc and cost of the main alternative fuels that can be used in internal combustion engines.

\begin{tabular}{cccccc}
\hline Type of Fuel & Methane & Octane & Propane & Ethanol & Methanol \\
\hline Cost (Euro $/ \mathrm{kg})$ & $0.05-0.1$ & $0.55-0.8$ & $0.4-0.75$ & $0.2-0.3$ & $0.15-0.25$ \\
Conversion temperature $(\mathrm{K})$ & 1000 & 1000 & 700 & 600 & 570 \\
\hline
\end{tabular}

From an economic point of view, it is advisable to use methanol as an alternative fuel for a diesel engine [22]. It should be pointed that methanol can be obtained from renewable sources too. There is a large raw material base to increase its production and much wider using as an energy source. Methanol is widely used in chemical industry and its considerable volumes are used in production of fuels for automobile motor vehicles [23]. Usage of this alcohol as an alternative biofuel for vehicles is possible as a result of its production in affordable and cheap ways from agricultural and food waste, from gaseous fuel. However, one of the most important reasons for the using of methanol is to reduce emissions of toxic components from the exhaust gases of automobile transport [24]. Currently, the main consumer of methanol is chemical industry. Methyl alcohol with its simpler structure and small molecule size is one of the determining factors for a "cleaner" combustion of fuel [25].

In comparison to other alternative fuels, the cost of methyl alcohol is rather low, and in addition, usage of methanol as a fuel for diesel engines can significantly reduce emissions of soot particles and nitrogen oxides. This is due to the fact that the combustion of methanol in the diesel cylinder does not form intermediates that promote the formation of acetylene and aromatic hydrocarbons, which lead to the formation of soot [26].

Methanol has a high octane number and a low level of fire hazard. It is poorly soluble in petroleum fuels. Temperature of exhaust gases of the engines working on a methanol mixture is $30-70{ }^{\circ} \mathrm{C}$ lower than the basic internal combustion engines [27]. Usage of liquefied methanol as a fuel is accompanied by increased wear of the cylinder-piston group caused by the ingress of its droplets on the walls of the cylinder and the destruction of the oil film.

\section{Materials and Methods}

\subsection{Fundamentals}

Thermo-chemical essentiality of the energy increasing of initial fuel represents the basic provisions of thermodynamics, in particular, Hess's law. It will be shown on the basis of analysis of thermal effects from combustion of methanol, which is based on two methods. According to the first and the second methods of methanol oxidation, the initial and final state of the system are the same: initial $-1 \mathrm{kmol} \mathrm{CH}_{3} \mathrm{OH}$, final $-2 \mathrm{kmol} \mathrm{H}_{2} \mathrm{O}$ and $1 \mathrm{kmol} \mathrm{CO}$.

According to the first method, methanol is burned directly in the combustion chamber of an internal combustion engine

$$
\mathrm{CH}_{3} \mathrm{OH}+3 / 2 \mathrm{O}_{2} \rightarrow 2 \mathrm{H}_{2} \mathrm{O}+\mathrm{CO}_{2}+Q_{M}
$$

where: $Q_{M}$ - exothermic thermal effect from the combustion of methanol-air mixture, and $Q_{M}=629,440 \mathrm{~kJ}[3]$.

As a result of reaction (1) by the first method, $3 \mathrm{kmol}$ of combustion products are formed.

According to the second two-stage method of methanol conversion, alcohol decomposed at first

$$
\mathrm{CH}_{3} \mathrm{OH} \rightarrow 2 \mathrm{H}_{2}+\mathrm{CO}-Q_{\mathrm{C}},
$$

It produces $2 \mathrm{kmol} \mathrm{H}_{2}$ and $1 \mathrm{kmol} \mathrm{CO}$ with endothermic heat conversion $Q_{C}$. 
Then, burn in oxygen $3 \mathrm{kmol}$ obtained by the reaction (2) of conversion products of methanol:

$$
\begin{aligned}
& 2 \mathrm{H}_{2}+\mathrm{O}_{2} \rightarrow 2 \mathrm{H}_{2} \mathrm{O}+481500 \mathrm{~kJ}, \\
& \mathrm{CO}+1 / 2 \mathrm{O}_{2} \rightarrow \mathrm{CO}_{2}+282600 \mathrm{~kJ},
\end{aligned}
$$

Total thermal effect:

$$
Q_{\Sigma}=282600+481500=764100 \mathrm{~kJ} / \mathrm{kmol}
$$

Thermal effects for reactions (3-4) are given according to the data [28]. Then, according to Hess's law total thermal effects for different routes of methanol oxidation must coincide:

$$
629440 \mathrm{~kJ} / \mathrm{kmol}=-Q_{C}+764100 \mathrm{~kJ} / \mathrm{kmol}
$$

Hence, the endothermic thermal effect of the conversion (methanol dissociation reaction) will be $Q_{C}=134,660 \mathrm{~kJ} / \mathrm{kmol}$.

Therefore, the calculation showed that thermal effect from combustion of the converted mixture of $\mathrm{CO}$ and $\mathrm{H}_{2}$ exceeds the effect from the combustion of the same amount of nonconvertible methanol (source fuel) by $Q_{C}=134,660 \mathrm{~kJ} / \mathrm{kmol}$ (i.e., $21.4 \%$ ), and it corresponds to the decomposition of alcohol energy.

The efficiency $\eta$ of this conversion, which is estimated by the thermal efficiency coefficient of the cycle, depends on the ratio of the average removal temperatures $T_{2}$ (lower temperature) and supply $T_{1}$ (upper temperature) of heat in the cycle [29]:

$$
\eta=\frac{T_{1}-T_{2}}{T_{1}}
$$

i.e., the higher the average heat transfers temperature at the considered level of heat removal temperature, the higher the thermal efficiency coefficient of the cycle.

It can be argued that implementation of such method is a priori possible only in presence of alternative fuels combustion of which at the same temperature would be accompanied by different levels of irreversible losses. Such fuels can be converted into new (artificial) fuels with higher energy potential by thermochemical transformations. Conversion of chemical energy of such artificial fuel into heat is accompanied by less irreversible losses.

This method of transferring chemical energy is developed on fundamental principles of thermochemistry and can be applied to any type of power plant. The proposed method provides for the necessity to organize the endothermic process of fuel conversion, which is based on the cycle of its thermochemical conversion, and on the operating cycle of the power plant provides for another process. If in a conventional power plant, the chemical energy of the fuel is converted into heat in one stage, then in the proposed method-in two.

In the first stage, the initial fuel is converted, and in the second one, the converted fuel is burned at a higher energy level. Two stages of energy conversion in the process of which the heat removed from the cycle is used allow to increase the energy efficiency of the initial fuel. In common case, efficiency of thermochemical regeneration depends on the type of power plant, method, and conditions of organization of working process, as well as the type of fuel, and endothermic effect of the reaction system of its conversion.

It should be noted that conversion products of traditional petroleum fuels obtained in a thermochemical reactor based on mechanism of exothermic reactions of incomplete oxidation of hydrocarbons have a lower heat of combustion in comparison to the initial fuel and this fact eliminates the effect of regeneration [30].

Let us calculate the combustion heat increasing of conversion products for liquefied methanol. Combustion heat of gaseous products of methanol conversion $H_{U . P . M}=23,870 \mathrm{~kJ} / \mathrm{kg}$ [31]. The heat of combustion of methanol $H_{U . M}=19,670 \mathrm{~kJ} / \mathrm{kg}$ (Table 2). 
Table 2. Comparative characteristics of the combustion heat of methanol and diesel fuel.

\begin{tabular}{cccc}
\hline Parameter & Diesel Fuel $\boldsymbol{H}_{U . D}$ & Methanol $\boldsymbol{H}_{U . M}$ & Converted Methanol $\boldsymbol{H}_{U . P . M}$ \\
\hline Absolute combustion heat $(\mathrm{kJ} / \mathrm{kg})$ & 42,500 & 19,700 & 23,870 \\
Relative combustion heat $(\%)$ & 100 & 46.35 & 56.17 \\
\hline
\end{tabular}

Thus, combustion in the engine of $1 \mathrm{~kg}$ of methanol conversion products obtained from the same mass of liquid methanol releases additional heat energy $H_{U . C}$ accumulated during conversion of alcohol fuel.

$$
H_{U . C}=H_{U . P . M}-H_{U . M}=4200 \mathrm{~kJ} / \mathrm{kg},
$$

Therefore, $21.4 \%$ of initial fuel energy is returned to the operating cycle of internal combustion engines for useful work.

This energy is obtained from utilization of thermal energy of exhaust gases during endothermic conversion in conditions of real operation of the internal combustion engine. According to external heat balance of the internal combustion engine, a significant part of chemical energy is not realized in the form of work and it is discharged into the surrounding space with exhaust gases too. In diesel engines, the component of energy losses in the heat balance reaches $25-40 \%$ [32]; in gasoline and gas engines, the part of irreversible heat loss lost from the engine with exhaust gases is $30-45 \%$. This corresponds to $13-22 \mathrm{MJ}$ of heat per $1 \mathrm{~kg}$ of consumed fuel.

Heat must be extracted from the exhaust manifold for ensuring the conversion process, where the temperature of the engine parts reaches from $700-800 \mathrm{~K}$ at idling speed to $1100-1200 \mathrm{~K}$ at maximum loads [33]. Even taking into account the heat loss during transferring of energy from the engine to the working body, it is absolutely easy to achieve the conversion temperature of methanol to $T_{m}=570 \mathrm{~K}$.

From the above, it follows that usage of pre-chemical conversion systems of alternative fuels can increase efficiency of its using in internal combustion engines by regenerating exhaust gases heat. For example, the thermodynamic cycle (Otto cycle) for diesel engines converted to gas with forced spark ignition with heat recovery can be represented by a T-S diagram (Figure 2).

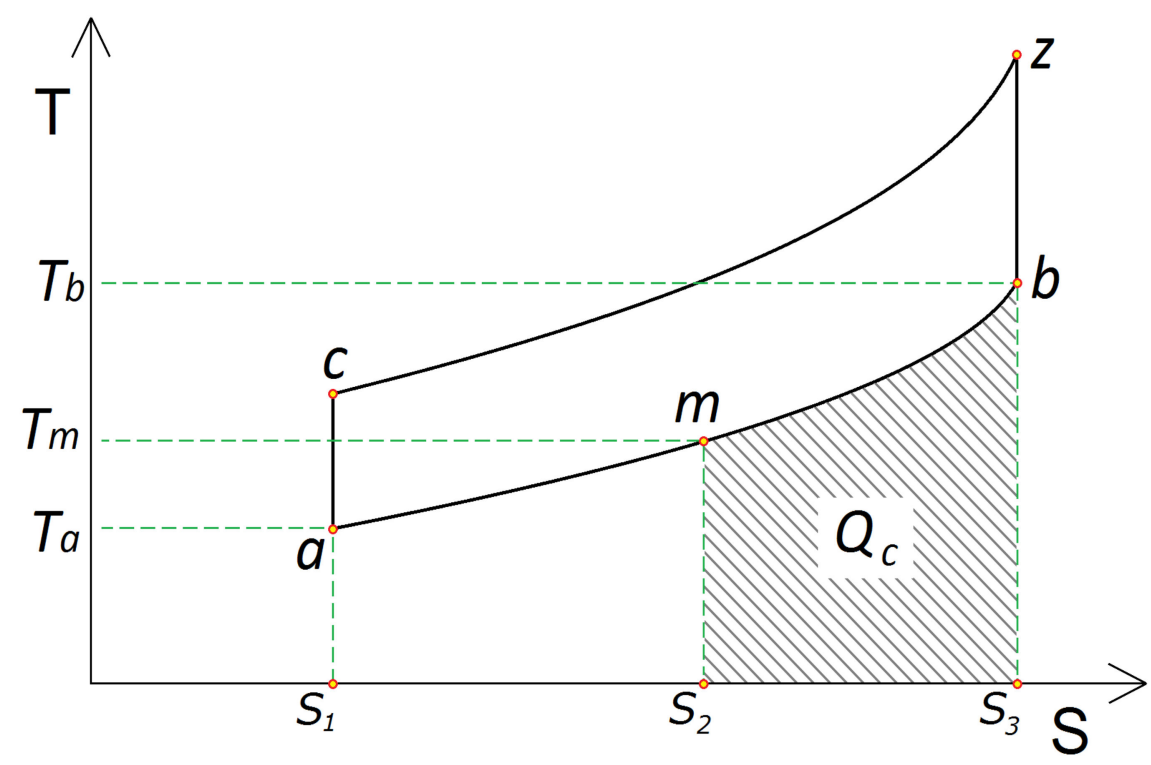

Figure 2. Thermodynamic cycle for diesel engines converted to gaseous products of methanol conversion with heat regeneration. $\mathrm{S}_{1}-\mathrm{c}-\mathrm{Z}-\mathrm{S}_{3}$-the supplied heat $Q s ; \mathrm{S}_{1}-\mathrm{a}-\mathrm{b}-\mathrm{S}_{3}$ - the waste heat $Q_{W}$; $\mathrm{S}_{2}-\mathrm{m}-\mathrm{b}-\mathrm{S}_{3}$ - the heat conversion suitable for regeneration $Q c$. 
In the diagram, heat suitable for regeneration in the cycle is expressed as part of the waste heat $Q_{W}$, i.e., the degree of regeneration $\eta_{p}$ is equal to [34]:

$$
\eta_{p}=\frac{Q_{C}}{Q_{W}}
$$

where $Q_{W}$ is the waste heat removed per cycle.

Heat quantity removed per cycle $Q_{W}$ (Figure 2) is determined from the expression

$$
Q_{W}=M_{p r . c} \cdot C_{\mu v}\left(T_{b}-T_{a}\right),
$$

where $M_{p r . c}$ is the number of combustion products at a constant volume; $C_{\mu v}$ is the average molar heat capacity of combustion products at constant volume.

Endothermic heat conversion quantity $Q_{C}$ is determined from (8) and from the expression

$$
Q_{C}=M_{p r . c .} \cdot C_{\mu v}\left(T_{b}-T_{m}\right),
$$

In other words, the regeneration degree $\eta_{p}$ depends on the conversion process temperature $T_{m}$ and it increases with decreasing of $T_{m}$ and it can be determined from the expression:

$$
\eta_{p}=\frac{T_{b}-T_{m}}{T_{b}-T_{a}} .
$$

Obviously, these requirements for the exhaust gases temperature level of the engine may not be met in all ranges of operation modes of internal combustion engines. For example, for an engine not warmed up to operating temperature, the regeneration of the conversion process degree will be reduced [35]. However, it should be noted that operating time of the engine in warm-up mode is quite short.

In addition, it should be noted that modern catalysts allow to implement the conversion of alternative fuels at lower operating temperatures. For example, for methanol it is $300-400{ }^{\circ} \mathrm{C}[36]$ and this fact determines the minimum possible temperature regime for organization the conversion process of exhaust gases in internal combustion engines. Therefore, we can talk about the possibility of almost constant conversion process in internal combustion engines due to heat recovery of exhaust gases for today.

Let us compare possibilities of energy conversion in two energetically similar internal combustion engines to analyze the possibility of efficiency increasing of chemical energy usage of fuel. The first one works according to the ordinary scheme, the second, using thermochemical regeneration in two stages. The required thermal mode of fuel conversion is provided by supplying heat to the exhaust gases.

The first engine works as follows. The initial fuel at the environment parameters enters to engine, where it burns with heat emitting $Q_{n}=N_{u}$. This heat is transferred to the working medium. Let us approximate that heat transfer occurs at an average temperature $T_{a v 1}$. Exhaust gases are discharged into the atmosphere after the cycle. To simplify the analysis, we assume that heat dissipation occurs at an average temperature $T_{a v 2}$.

Then, the work $L_{m}$ performed by the engine can be determined as follows

$$
L_{m}=H_{U . M} \frac{T_{a v 1}-T_{a v 2}}{T_{a v 1}},
$$

The efficiency $\eta$ of chemical energy using for fuel is equal to:

$$
\eta=\frac{L_{m}}{H_{U . M}}=\frac{T_{a v 1}-T_{a v 2}}{T_{a v 1}} .
$$

Dependence (14) determines the efficiency coefficient of the thermal power plant, which is equal to the ratio of quantity of energy converted into work to the whole energy received into the thermal power plant. Efficiency coefficient of this idealized plant coin- 
cides with the thermal efficiency coefficient of the cycle. This indicates that in an engine without thermochemical regeneration the energy efficiency of fuel depends entirely on the conversion of heat into work and cannot exceed the efficiency of conversion of the latter one.

The second engine works with thermochemical regeneration of exhaust gas heat. Unlike the first engine, fuel enters the combustion chamber not immediately but preundergoes the stage of thermochemical processing in a thermochemical reactor. There is thermochemical conversion of the initial fuel into convertible in the reactor with the help of the heat coming at the average lower temperature $T_{a v 2}$, and it goes to the combustion chamber of the engine. Assuming that the heat exchange in this engine is carried out similarly to the first option, the working body of the second engine with a thermochemical reactor must receive heat even at medium temperature $T_{a v 1}$.

Then, in this case, the heat taken by the working body $H_{U . P . M}$ exceeds the combustion heat $H_{U . M}$ of initial fuel by the quantity $H_{U . C}$ that was absorbed during the thermochemical conversion of the source fuel in the thermochemical reactor and is accordingly equal to:

$$
H_{U . P . M}=H_{U . M}+H_{U . C} .
$$

We will assume that the engine with a thermochemical reactor converts the heat perceived by the working body with the same efficiency as the engine without a thermochemical reactor, i.e., the thermal efficiency coefficient of both units is the same. Then, the work $L_{p . m}$ that the engine with a thermochemical reactor can do will be equal to:

$$
L_{p . m}=\left(H_{U . M}+H_{U . C}\right) \frac{T_{a v 1}-T_{a v 2}}{T_{a v 1}} .
$$

Then, the efficiency $\eta_{n . m}$ of fuel energy in the engine containing the unit of thermochemical heat regeneration will be determined from the expression:

$$
\eta_{n . m}=\left(\frac{H_{U . M}+H_{U . C}}{H_{U . M}}\right)\left(\frac{T_{a v 1}-T_{a v 2}}{T_{a v 1}}\right)=\frac{H_{U . P . M}}{H_{U . M}}\left(\frac{T_{a v 1}-T_{a v 2}}{T_{a v 1}}\right) .
$$

Let us analyze the efficiency of fuel energy usage in an engine containing the thermochemical regeneration unit and working on methanol in comparison to the ordinary engine. Let us take the average upper temperature of the cycle $T_{a v 1}=2000 \mathrm{~K}$, and the lower average one $-T_{a v 2}=1200 \mathrm{~K}$. Then, according to dependence (14), we have the thermal efficiency coefficient of an ordinary engine $\eta_{M}=40 \%$. As shown above, the heat of combustion of methanol $H_{U . M}$ is $19,670 \mathrm{~kJ} / \mathrm{kg}$. The heat of combustion of gaseous products of methanol conversion $H_{U . P . M}$ is $23,870 \mathrm{~kJ} / \mathrm{kg}$. Then, for an engine with thermochemical regeneration, its thermal efficiency coefficient $\eta n \cdot M$ will exceed the thermal efficiency coefficient $\eta_{M}$ of the first engine in by $(23,870 / 19,670)=1.214$ times, i.e., for an engine with thermochemical regeneration, its thermal efficiency coefficient will be equal to $\eta_{P . M}=48.5 \%$.

From the above analysis, it follows that the irreversible external losses of fuel chemical energy conversion into heat in case of using the method of thermochemical heat regeneration of exhaust gases are always less than corresponding losses in direct combustion of fuel without prior thermochemical processing. Moreover, the reduction of irreversible losses is adequate to the energy that must be spent to compensate for the total thermal endothermic effect of conversion reactions of initial fuel.

The theoretical foundations of such power supply systems for internal combustion engines in modern research practice remain poorly understood [17,37-39]. However, they are of significant interest in terms of assessing the potential applications of thermochemical regeneration engines in power supply systems and improving the energy efficiency of alternative fuels, in particular for existing diesel engines that will be converted to gas.

The implementation of a thermochemical method of heat utilization for the operating cycle conditions of internal combustion engines with spark ignition is possible if initial fuel is hydrocarbon compounds with a relatively low temperature of conversion reactions 
(alcohols, ethers and similar compounds). Gaseous conversion products can be used as the main fuel to power the gas engine [5]. It is important to be able to implement this method in power supply systems of diesel engines that are converted to gaseous fuels [40].

Let us analyze the conditions for achieving the maximum possible degree of regeneration. The conditions for achieving the maximum possible degree of regeneration are implemented when the endothermic effect of the conversion reaction corresponds to the supply of an equivalent quantity of heat to the reaction space from an external sourceheating coolant and it acts exhaust gases heat of the engine and may be the heat of the cooling system [41].

In real conditions, the conversion process in the exhaust system of the internal combustion engine coolant (exhaust gases and coolant) must have a potentially higher level of energy, which is used not only to compensate for the endothermic effect of the conversion reaction, but also to organize its auxiliary cycles [42]. Energy is required to preheat the source fuel to the boiling point, its evaporation, increase the vapor temperature to the dissociation temperature, compensate for heat loss to the environment through the walls of the reactor, and supply pipelines.

For example, the total heat consumption for a fully completed conversion of $1 \mathrm{~kg}$ of methanol reaches $7 \mathrm{MJ}$ [43]. At the same time, to compensate for endothermic effect, the alcohol conversion spent is about $60 \%$ of total energy losses. A significant part of them (about 25\%) is spent on the energy-intensive process of vaporization (heat of evaporation of methanol 1.1 MJ $/ \mathrm{kg}$ ). That means that the maximum possible degree of regeneration is achieved when the thermal energy of the coolant exceeds the total energy required for the conversion process.

\subsection{Equipment Used}

The aim of experimental studies is using methanol conversion products in alternative fuel mixtures in existing diesel engines to save petroleum motor fuel and improve their environmental performance.

Evaluation of effectiveness of the thermochemical method of heat utilization in the operating cycle of the diesel type D21A was performed in the laboratory on a motor stand. A brief technical description of the experimental diesel engine D21A1 is shown in Table 3.

Table 3. Brief technical characteristics of the experimental diesel engine D21A1.

\begin{tabular}{ccc}
\hline The Name of the Engine Parameters & Unit & Meaning \\
\hline Type of diesel engine & - & 2-cylinder, 4-stroke, air-cooled \\
Diesel engine displacement & $\mathrm{L}$ & 2.08 \\
Diesel engine weight & $\mathrm{kg}$ & 280 \\
The method of mixing & - & Direct injection of diesel fuel \\
Rated engine power & $\mathrm{kW}$ & 18.4 \\
Efficient specific fuel consumption & $\mathrm{g} / \mathrm{kWh}$ & 248 \\
Crankshaft speed at rated power & $\mathrm{rpm}$ & 1800 \\
Crankshaft speed at idling speed & $\mathrm{rpm}$ & 800 \\
\hline
\end{tabular}

A scheme of the experimental stand based on the diesel engine D21A1 for research of indicators of its work to products of methanol conversion is shown in Figure 3.

To ensure cold start of the engine, operating in the mode of methanol conversion products, in front of the gas reducer was assembled liquid coolant heater Webasto Thermo Top C (5 kW). The liquid coolant heater was turned off when the exhaust gases reached temperature of $300^{\circ} \mathrm{C}$. The thermocatalytic methanol conversion reactor was installed in the diesel exhaust system in the immediate vicinity of the exhaust manifold (Figure 4). 


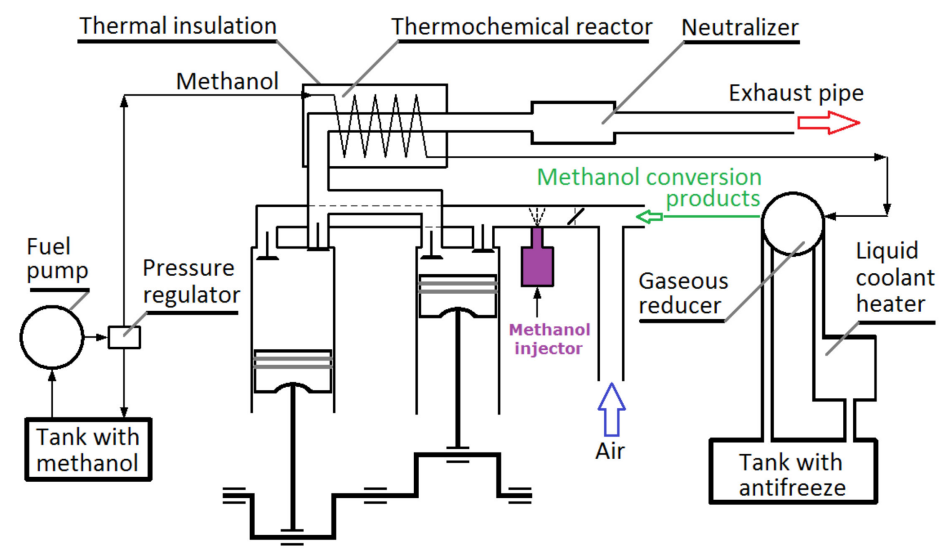

Figure 3. Scheme of the experimental stand based on the diesel engine D21A1 for study parameters of its work of methanol conversion products.

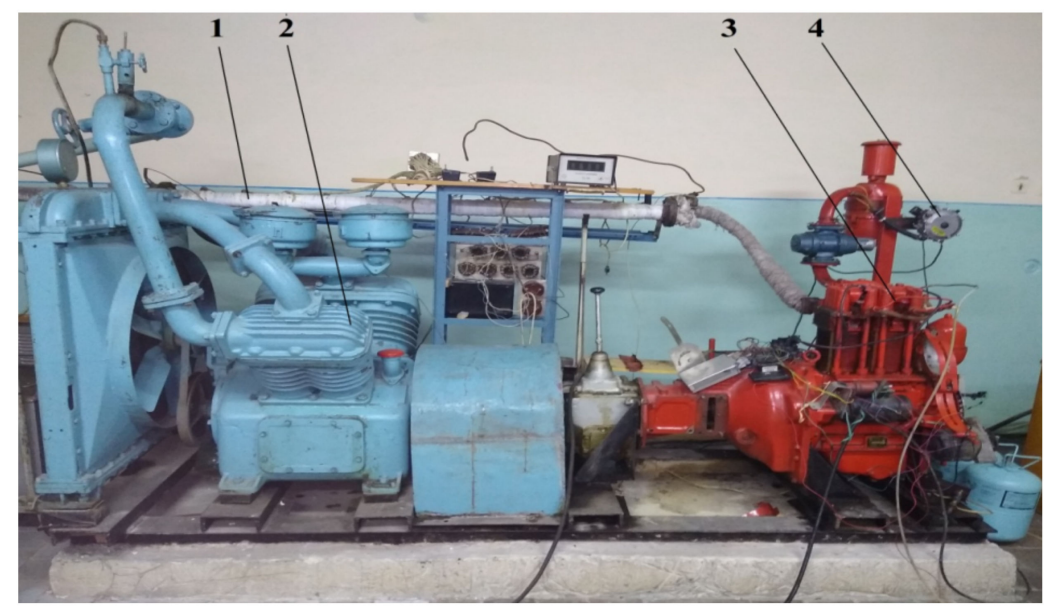

Figure 4. Appearance of the experimental stand based on the diesel engine D21A1 for the study of parameters on alternative fuel mixtures. 1-thermochemical reactor; 2-loading device of the internal combustion engine; 3-D21A1 diesel engine; 4-gas reducer.

Fuel-air mixture was ignited using an electronic ignition system of our own design. The developed original electronic ignition system consists of a control unit 1 (Figure 5), which changes the angle of ignition advance depending on the mode of operation of the engine.

The D21A1 diesel engine was converted to work on an alternative gas mixture. For this reason, diesel injectors were dismantled from the unit heads, additional threads were cut in the injector spray channels, and spark plugs were installed. The diesel engine D21A1 with the dismantled heads of the block is shown in Figure 6.

Design of the engine head is redesigned in such a way that, instead of spark plugs, one can easily screw back the diesel injectors. Such conversion of experimental engine allows switching to diesel or methanol fuel during $10 \mathrm{~min}$ by replacement of diesel injectors to spark plugs. Conversion from diesel fuel to gas heads of the engine block D21A1 is shown in Figure 7. 


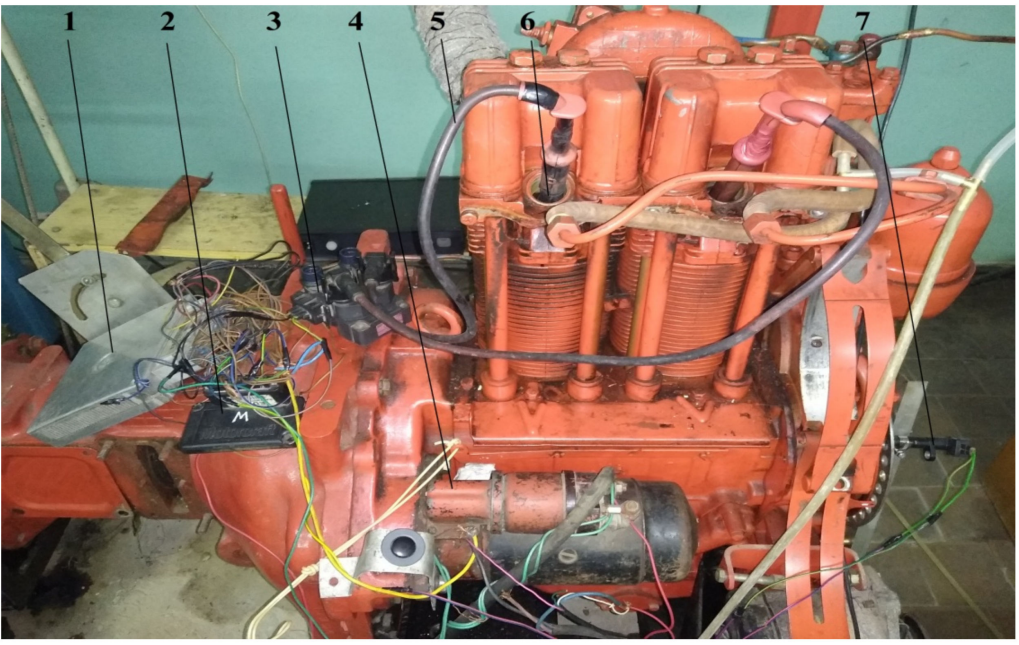

Figure 5. Ignition system of the converted diesel engine D21A1: 1-electronic control unit; 2commutator; 3-ignition module; 4-starter; 5-high-voltage wires; 6—spark plugs; 7—sensor of crankshaft position.

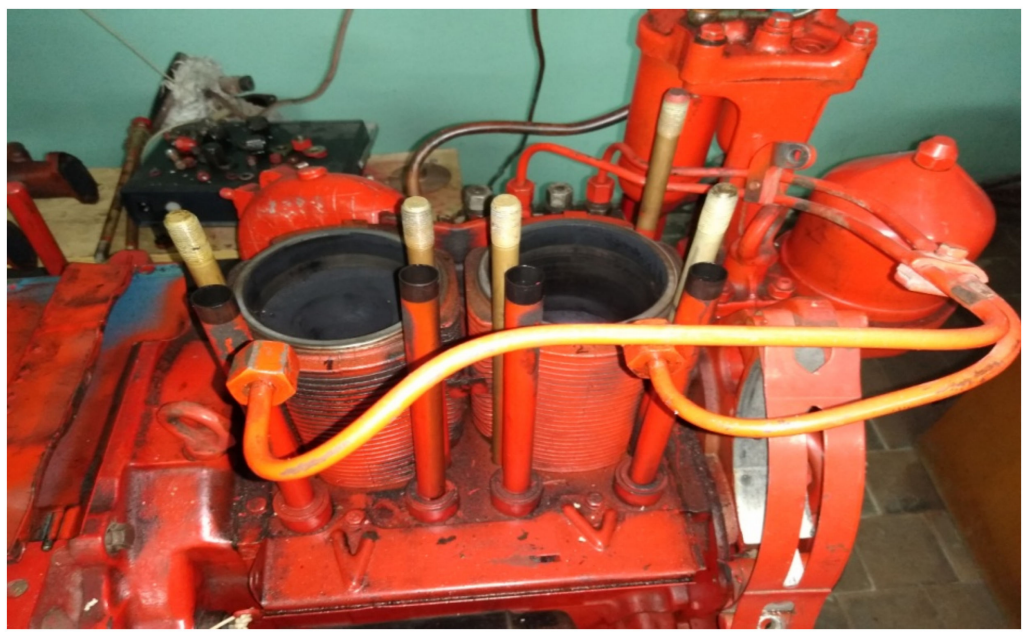

Figure 6. D21A1 diesel engine with dismantled unit heads.

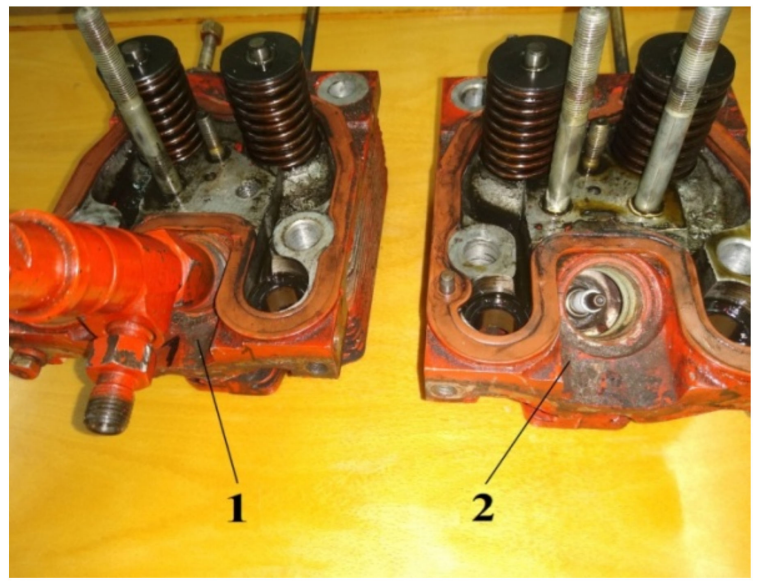

(a)

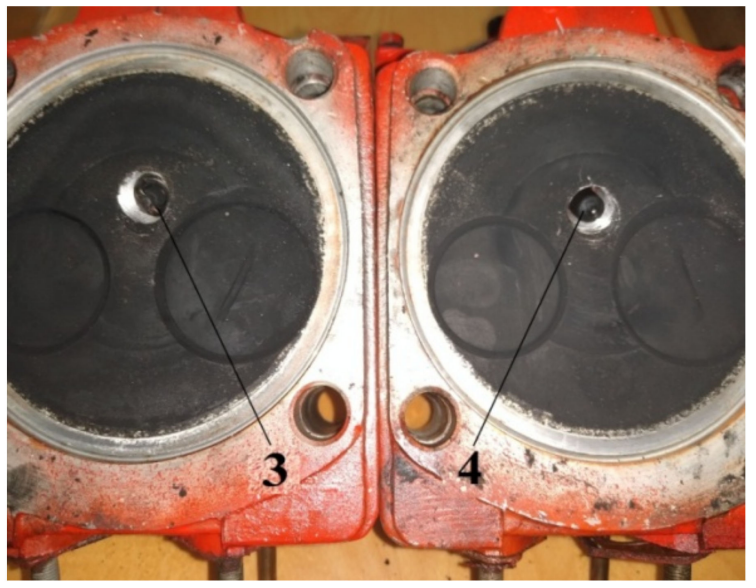

(b)

Figure 7. Conversion from diesel to gas fuel heads of the unit. View from the timing valves (a) and the combustion chamber (b) 1—the head of the block before re-equipment with the established diesel injector; 2 -the head of the block after re-equipment with the dismantled injector and the established spark plug; 3—spark plug; 4—diesel injector. 


\subsection{Testing Methodology}

The experimental stand engine could work in three modes: supply of diesel fuel in the liquefied phase through the injectors; supply of methanol conversion products through a gas reducer; and supply of methanol in the liquefied phase through the injectors. Methanol was supplied from the fuel tank by an electric fuel pump through the fuel pressure regulator. The fuel pressure regulator provides supply of methanol at pressure of $0.5 \mathrm{MPa}$ to compensate relatively low heat of methanol combustion and increase its supply. Throttle pipe with a throttle valve was mounted on the engine to ensure regulation of the methanol-air mixture. Methanol is heated to get conversion products by exhaust gases or liquid coolant heater during cold engine start-up and warm-up.

During the research, the engine worked with a full load at engine speeds of 800,900 , $1000,1100,1200,1300,1400,1500,1600,1700$, and $1800 \mathrm{~min}^{-1}$. The measurements were carried out according to the methods developed on the basis of GOST 14846-91 on the stationary operation modes of the engine. The preliminary determination of amount of toxic components in exhaust gases was carried out using the gas analyzer Autotest 02.03P by direct measurement. Graphing and final determination of the amount of toxic components in exhaust gases was carried out with the NeoCHROM Class $\mathrm{C}$ gas chromatograph. Exhaust gas samplers were installed at a distance of $1 \mathrm{~m}$ from the outlet from the exhaust system. Measurement of the amount of toxic components in exhaust gases was carried out by taking samples into sampling bags. An adsorption type infrared non-dispersive detector was used for the analysis of carbon oxides. A heated flame ionization detector was used for hydrocarbon analysis. A chemiluminescence detector was used to analyze nitrogen oxides. The air/methanol ratio was: $6.45 \mathrm{~kg}$ of air $/ 1 \mathrm{~kg}$ of methanol when measuring of toxic components in exhaust gases. The air/methanol ratio when measuring the power was: $6.45 \mathrm{~kg}$ of air $/ 1 \mathrm{~kg}$ of methanol and $14.3 \mathrm{~kg}$ of air $/ 1 \mathrm{~kg}$ of methanol (in comparison). Tanks with methanol and diesel fuel were placed on electronic scales and the mass of consumed fuel was determined using electronic scales. The weight of air on the inlet was calculated on the measured volume, temperature, and pressure of air.

The purpose of experimental research was to compare the main power, fuel-economic, and environmental characteristics of the converted diesel engine during its operation on diesel fuel and methanol conversion products. Experimental studies were performed on the motor stand of the D21A1 engine to evaluate the energy-saving effect.

\section{Results and Discussion}

Experimental dependences of external speed characteristics of the diesel engine D21A1 fuelled with diesel fuel, methanol fuel, and methanol conversion products are shown in Figure 8. It was found, analyzing experimental power values, that at nominal speed $\left(n=1800 \mathrm{~min}^{-1}\right)$, the effective power $N$ for diesel fuel was $18.1 \mathrm{~kW}$, but for the products of methanol conversion, it was equal $10.1 \mathrm{~kW}$ (1 kg of methanol/14.3 kg of air). On average, the value of the effective power $N$ of the engine in the entire frequency range of the crankshaft in comparison to diesel fuel working on methanol conversion products $(1 \mathrm{~kg}$ of methanol $/ 14.3 \mathrm{~kg}$ of air) decreased by $45 \%$.

It was found, analyzing experimental power values, that at nominal speed $\left(n=1800 \mathrm{~min}^{-1}\right)$, the effective power $N$ for methanol fuel (1 kg of methanol $/ 6.45 \mathrm{~kg}$ of air) was $17.1 \mathrm{~kW}$, but on the products of methanol conversion ( $1 \mathrm{~kg}$ of methanol $/ 6.45 \mathrm{~kg}$ of air), it was equal to $21.2 \mathrm{~kW}$ (1 $\mathrm{kg}$ of methanol $/ 6.45 \mathrm{~kg}$ of air). On average, the value of the effective power $N$ of the engine in the entire frequency range of the crankshaft in comparison to diesel fuel working on methanol fuel ( $1 \mathrm{~kg}$ of methanol $/ 6.45 \mathrm{~kg}$ of air) decreased by $5 \%$; for methanol conversion products ( $1 \mathrm{~kg}$ of methanol $/ 6.45 \mathrm{~kg}$ of air), it increased by $14 \%$. 


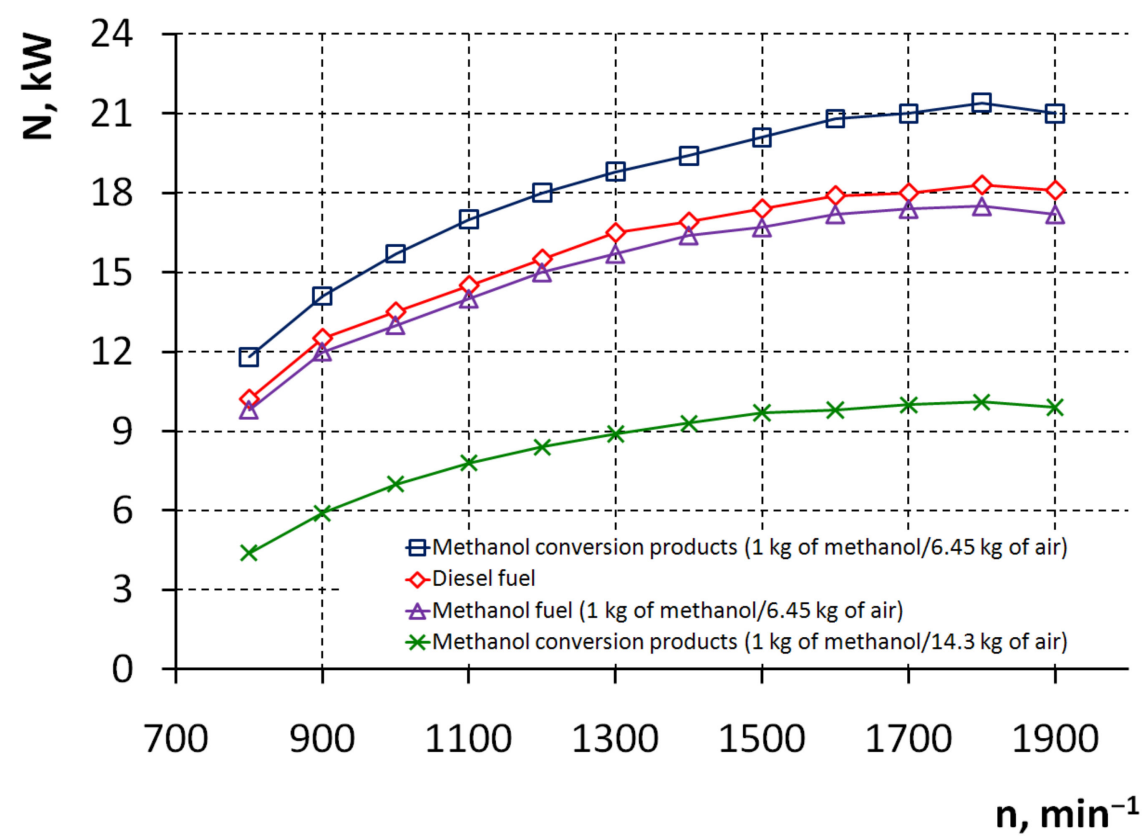

Figure 8. Experimental dependences of the effective power $N$ on the engine crankshaft speed $n$ for different motor fuels.

The experimental dependences of specific fuel consumption $g_{e}$ on the crankshaft speed $n$ of the diesel engine D21A1 fuelled with diesel fuel, methanol fuel, and methanol conversion products are shown in Figure 9. It was found, analyzing the experimental power values, that for diesel fuel, a minimum specific fuel consumption at $1200 \mathrm{~min}^{-1}$ was $212 \mathrm{~g} / \mathrm{kWh}$ and $248 \mathrm{~g} / \mathrm{kWh}$ at nominal speed $n=1800 \mathrm{~min}^{-1}$. In case of engine fuelled with the methanol conversion products, the minimum value of specific fuel consumption was $386 \mathrm{~g} / \mathrm{kWh}$ and $451 \mathrm{~g} / \mathrm{kWh}$ at nominal speed. Minimum specific fuel consumption was $460 \mathrm{~g} / \mathrm{kWh}$ for methanol fuel and $545 \mathrm{~g} / \mathrm{kWh}$ at $1800 \mathrm{~min}^{-1}$.

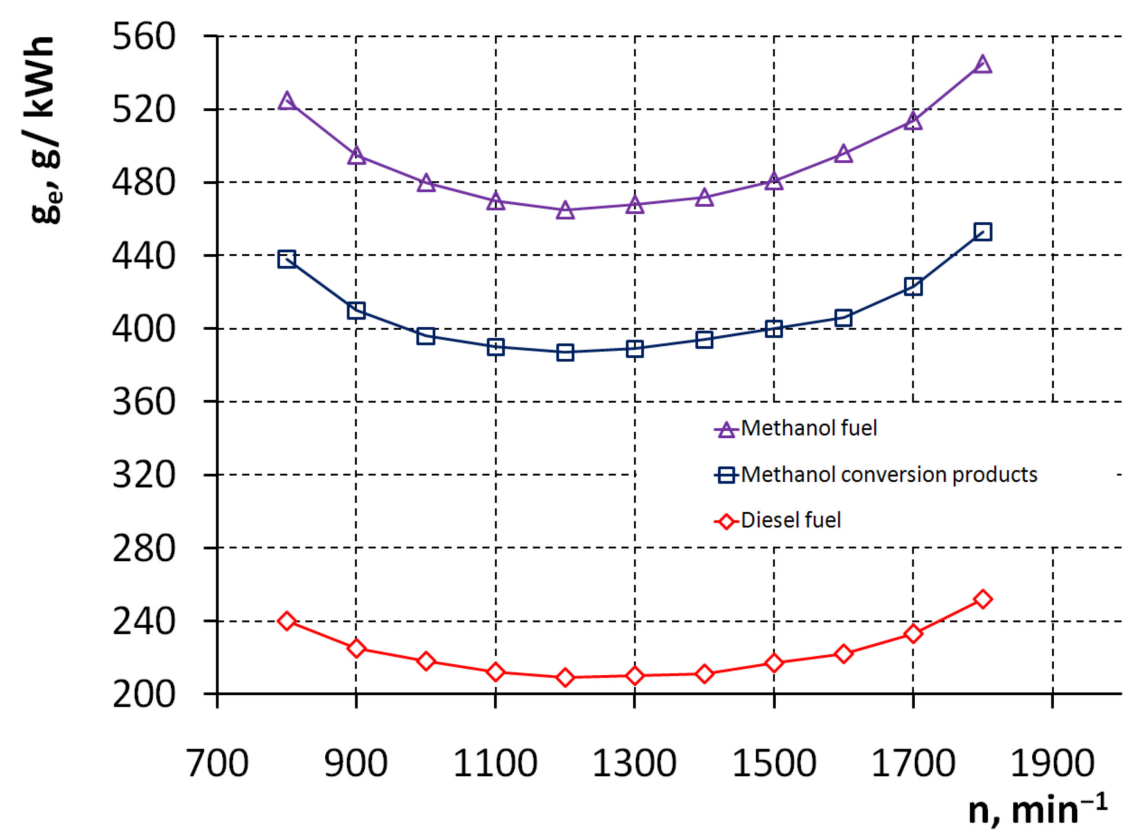

Figure 9. Experimental dependences of specific fuel consumption on the crankshaft speed of the engine $n$ for different motor fuels. 
On average, specific fuel consumption from the engine crankshaft speed in the entire range of the crankshaft speed in comparison to diesel fuel working on $100 \%$ of methanol conversion products increased by $80-84 \%$. On average, specific fuel consumption from the engine crankshaft speed in entire range of the crankshaft speed in comparison to diesel fuel working on $100 \%$ of methanol fuel increased by $116-120 \%$. The specific fuel consumption of the studied fuels is very different according to Figure 9. Therefore, we will do a comparison of effective performance.

The mass energy intensity (combustion heat) of methanol $(19.7 \mathrm{MJ} / \mathrm{kg})$ is $46 \%$ of the mass energy intensity of diesel fuel $(42.5 \mathrm{MJ} / \mathrm{kg})$. However, the combustion heats of methanol-air and diesel-air mixtures are little different in the case of their combustion in the engine, because, for combustion of $1 \mathrm{~kg}$ of methanol, it requires $6.45 \mathrm{~kg}$ of air, and for combustion $1 \mathrm{~kg}$ of diesel fuel, it requires $14.3 \mathrm{~kg}$ of air (stoichiometric ratio). Despite the fact of combustion of $1 \mathrm{~kg}$ of methanol released less heat $(19.7 \mathrm{MJ} / \mathrm{kg})$ than for combustion of $1 \mathrm{~kg}$ of diesel fuel $(42.5 \mathrm{MJ} / \mathrm{kg}$ ), effective performances (energy ratio per $1 \mathrm{~kg}$ of fuel mixture) are comparable. For example, the combustion heat of methanolair mixes is $19.7 /(1+6.45)=2.64 \mathrm{MJ} / \mathrm{kg}$. The combustion heat of diesel-air mixtures is $42.5 /(1+14.3)=2.78 \mathrm{MJ} / \mathrm{kg}$. That is $95.0 \%$ of the combustion heat of methanol-air mixture from the combustion heat of diesel-air mixture.

For methanol conversion products, the combustion heat of methanol-air mixtures is $23.9 /(1+6.45)=3.21 \mathrm{MJ} / \mathrm{kg}$. That is $115.5 \%$ of the combustion heat of methanol-air mixture of methanol conversion products using the reactor from the combustion heat of diesel-air mixtures.

These data suggest that methanol is not the best fuel for engines. However, additional analysis of the fuel energy conversion efficiency confirms that combustion of the methanol conversion products implies expected energetic benefits. Figure 10 clearly indicates that the fuel conversion efficiency calculated for the engine powered with methanol conversion products is by $20 \%$ higher in comparison to the engine fuelled with diesel fuel.

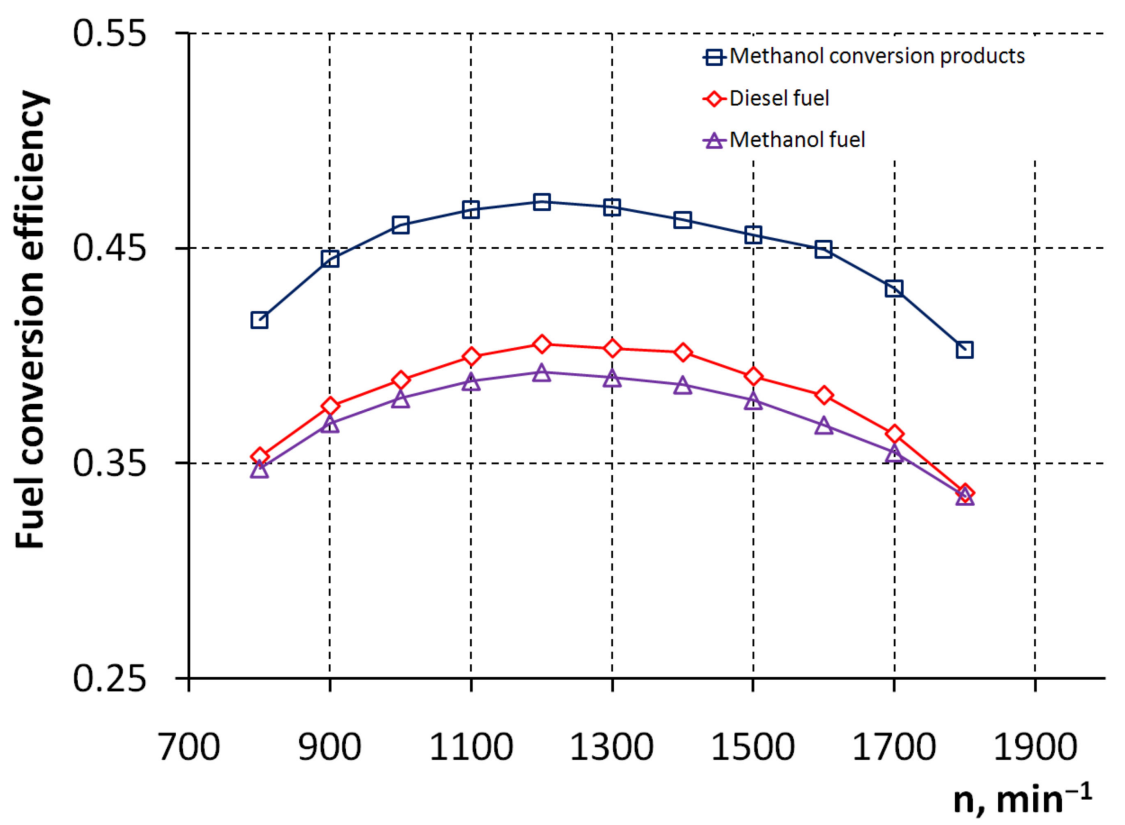

Figure 10. Energy conversion efficiency obtained for the engine fuelled with diesel fuel, methanol, and methanol conversion products.

Analyzing the change in content of toxic components in exhaust gases during transition from diesel to methanol conversion products ( $1 \mathrm{~kg}$ of methanol $/ 6.45 \mathrm{~kg}$ of air), the following can be noted. There is a significant decrease in the content of nitrogen oxides in the entire frequency range of the crankshaft (Figure 11). Thus, at $n=1200 \mathrm{~min}^{-1}$, the content of nitrogen oxides decreased from $68 \mathrm{ppm} / \mathrm{kW}$ when the engine is running on 
diesel fuel to $53 \mathrm{ppm} / \mathrm{kW}$ when the engine is running on the products of methanol conversion. That means that the decrease in the content of nitrogen oxides was $22 \%$. At nominal crankshaft speed $1800 \mathrm{~min}^{-1}$, the content of nitrogen oxides decreased from $45 \mathrm{ppm} / \mathrm{kW}$ when the engine is running on diesel fuel to $29 \mathrm{ppm} / \mathrm{kW}$ when the engine is running on the products of methanol conversion. That means that the decrease in the content of nitrogen oxides was 35\%. The decrease in the content of nitrogen oxides during the operation of the engine on diesel fuel in comparison with the operation of the engine on the products of methanol conversion is explained by lower heat dissipation rates and less increase in combustion pressure in the engine.

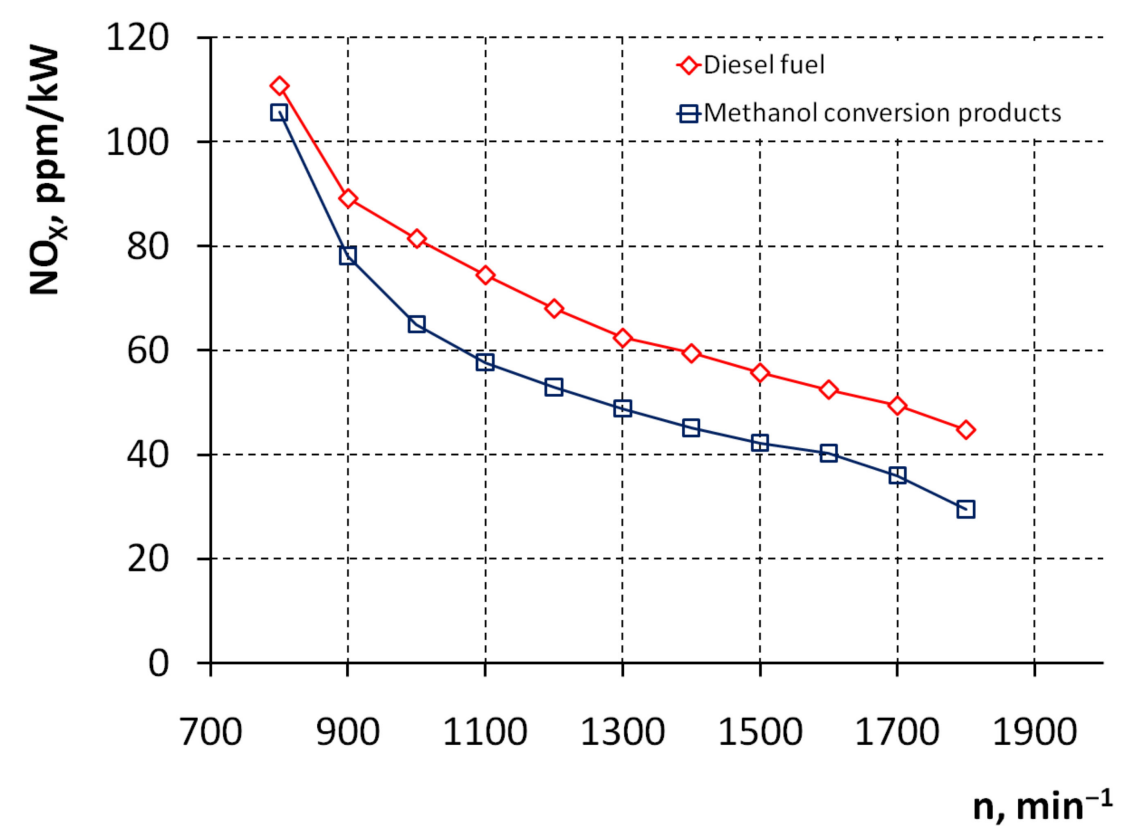

Figure 11. Experimental dependences of the content of nitrogen oxides in exhaust gases on the crankshaft speed of the engine $n$ for different motor fuels.

There is a significant decrease in the content of carbon monoxide in the entire frequency range of the crankshaft (Figure 12). Thus, at $n=1200 \mathrm{~min}^{-1}$, the content of carbon monoxide decreased from $0.013 \%$ per $\mathrm{kW}$ when the engine is running on diesel fuel to $0.0098 \%$ per $\mathrm{kW}$ when the engine is running on the products of methanol conversion. Only at nominal speed $1800 \mathrm{~min}^{-1}$, the carbon monoxide content is the same for both tested fuels.

The hydrocarbon content increases slightly in the entire range of crankshaft speed (Figure 13). Thus, at $n=1200 \mathrm{~min}^{-1}$, the hydrocarbon content varies from $0.0032 \mathrm{ppm}$ per $\mathrm{kW}$ when the engine is running on diesel fuel to $0.0064 \mathrm{ppm}$ per $\mathrm{kW}$ when the engine is running on methanol conversion products. That means that the increase in hydrocarbon content was $100 \%$. At $n=1800 \mathrm{~min}^{-1}$ (nominal speed), the hydrocarbon content increases from $0.004 \mathrm{ppm}$ per $\mathrm{kW}$ when the engine is running on diesel fuel to $0.015 \mathrm{ppm}$ per $\mathrm{kW}$ when the engine is running on methanol conversion products. That means that increasing in hydrocarbons was almost 4 times.

There was an additional experimental study to identify factors of improving fuel economy of the experimental engine. In the first stage of tests using a gas-balloon supply system, synthesis gas was fed into the engine cylinders, which has a component composition (volume fractions) similar to the composition of methanol conversion products: $33 \%$ $\mathrm{CO}$ and $67 \% \mathrm{H}_{2}$.

It is obvious that, in this case, the effect of utilization of thermal energy of exhaust gases is not shown. In the second stage of testing, the engine worked in conjunction with a thermochemical reactor. The utilized energy of the exhaust gases converted into a new type of gaseous fuel (methanol conversion products) with higher energy parameters was 
used for additional useful work. That means that the engine worked on the scheme of the regenerative cycle.

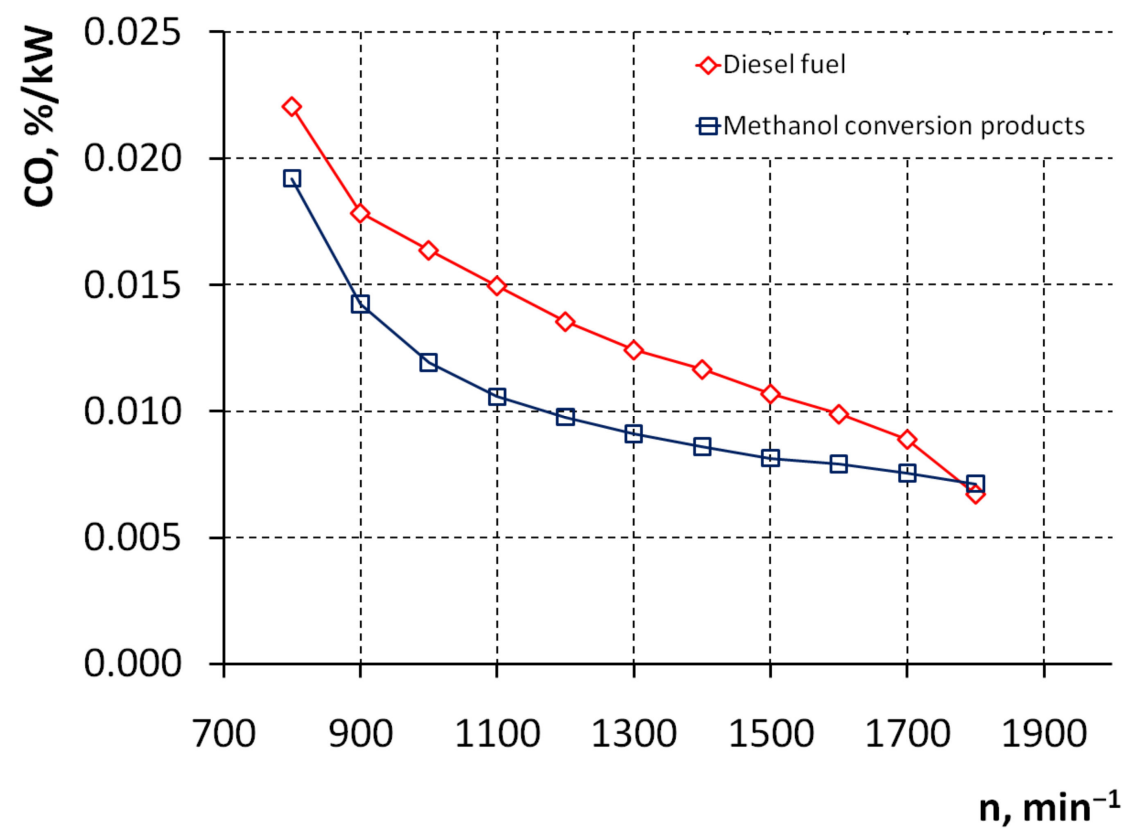

Figure 12. Experimental dependences of the content of carbon monoxide in the exhaust gases on the crankshaft speed of the engine $n$ for different motor fuels.

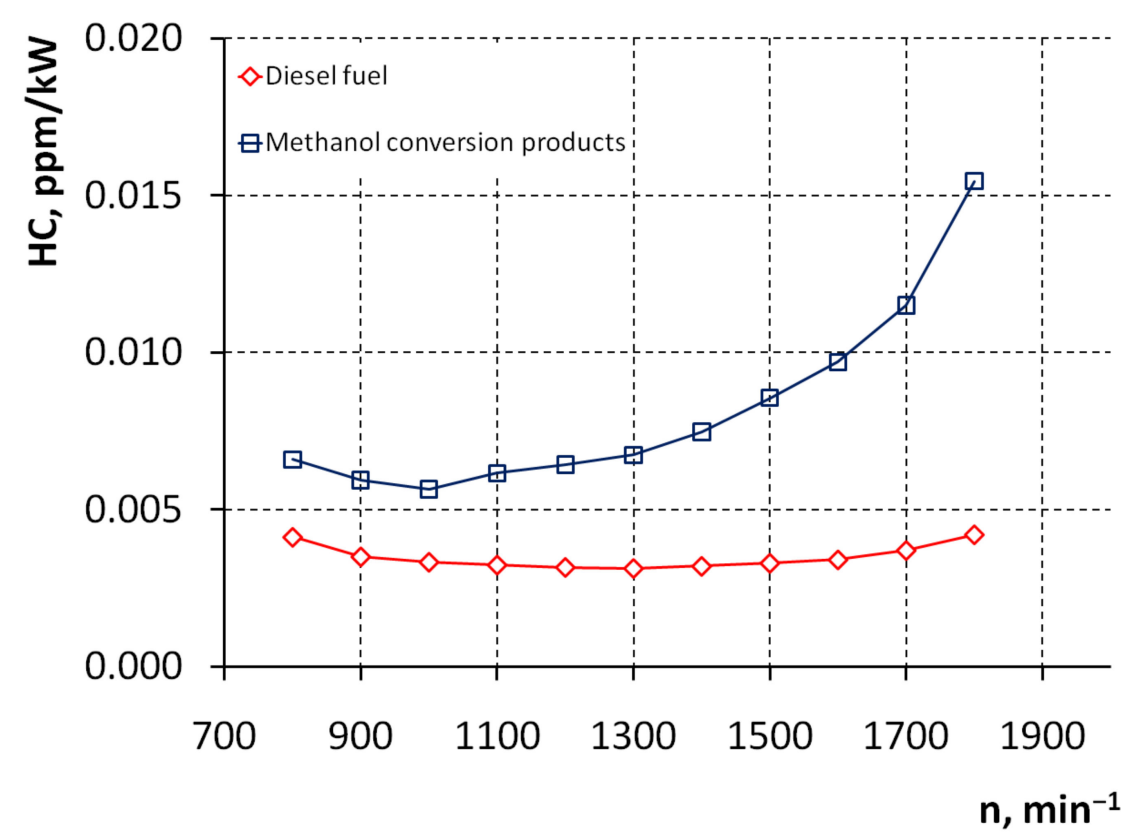

Figure 13. Experimental dependences of the hydrocarbon content in the exhaust gases on the crankshaft speed of the engine $n$ for different motor fuels.

Considering the fact that, in both cases, fuel had the same component composition, its combustion parameters and, hence, the nature of the impact on the kinetic parameters of the operating cycle were identical. Therefore, the increasing of engine efficiency, which was observed in experimental studies, clearly corresponded to the effect of thermochemical regeneration of exhaust energy. 


\section{Conclusions}

Research studies have shown that conversion of diesel engines to work using methanol conversion products is quite profitable.

It is established that the efficiency of the engine at idling mode depends on its speed. On average, the specific fuel consumption from the engine crankshaft speed in the entire range of the crankshaft speed compared to diesel fuel working on $100 \%$ of methanol conversion products increased by $82 \%$. As the price of methanol is, on average, $10-20 \%$ of the cost of diesel fuel, therefore, the conversion of diesel engines for work using methanol conversion products is very profitable.

Economic parameters of operating cycle at all loading modes of the engine with a thermochemical reactor were higher (on average by 10-14\%) than it worked on methanol without a thermochemical reactor. Operating cycle parameters almost corresponded to the basic parameters of the engine during its work on liquefied methanol at low crankshaft speeds (from 800 to $1000 \mathrm{~min}^{-1}$ ), characterized by low temperature and energy levels of exhaust gases. The most significant increase in the fuel conversion efficiency (by 20\% compared to work on liquefied methanol) was observed in the range of shaft speed 1200-1400 $\mathrm{min}^{-1}$ at an exhaust gas temperature of $400-450{ }^{\circ} \mathrm{C}$. This is due to the fact that, in this range of speeds, the reactor consumed thermal energy and the energy of the coolant are almost the same.

The improvement of economic parameters of the studied diesel engine with thermochemical method of heat utilization running on mixed hydrogen-containing fuel is due to the influence of two factors: the effect of partial utilization of exhaust gas heat and improvement of kinetic combustion in the presence of hydrogen.

Reduction of fuel consumption was accompanied by an improvement in the environmental parameters of the diesel engine, which works in conjunction with a thermochemical methanol conversion reactor. In particular, depending on the crankshaft speed and the load on the engine formation of nitrogen oxides in the exhaust gases decreased by $22-35 \%$, carbon monoxide occurred in the range of $0-24 \%$.

Studies have shown that in loading modes, when the temperature of the exhaust gases at the inlet to the reactor exceeds $400{ }^{\circ} \mathrm{C}$, the reactor productivity including the target hydrogen component reaches its highest level significantly increasing the efficiency of the operating cycle.

Application of the considered method of energy utilization of exhaust gases in transport engines is quite promising. Its implementation does not require large financial investments and radical re-equipment of existing engine production due to technical simplicity.

Any serial model of diesel engines can be used as the base engine. This applies to both in-service engines and new engines. The main element of the conversion systemthermochemical reactor-is the simplest design of the heat exchanger, the mass and dimensions of which in the volume of a conventional silencer provide convenience of its installation in the exhaust system of the engine.

An important stimulus for the further development of such systems is determining the possibility of cumulative improvement of vehicle characteristics on a set of parameters. Their implementation on vehicles allows, in particular, to utilize waste thermal energy, improve combustion processes, improve environmental quality of vehicles, providing the opportunity to replace traditional petroleum fuel with alternative energy from renewable, including biological sources, thus helping to solve the global problem of resource conservation.

Author Contributions: Conceptualization, S.K. and K.G.; methodology, R.L.; software, L.K.; validation, R.S. and R.L.; formal analysis, S.K.; investigation, R.L.; resources, S.K. and R.S.; data curation, K.G.; writing—original draft preparation, L.K., K.G., and R.S.; writing—review and editing, L.K., K.G., and R.S. All authors have read and agreed to the published version of the manuscript.

Funding: This research received no external funding.

Institutional Review Board Statement: Not applicable. 
Informed Consent Statement: Not applicable.

Data Availability Statement: Not applicable.

Conflicts of Interest: The authors declare no conflict of interest.

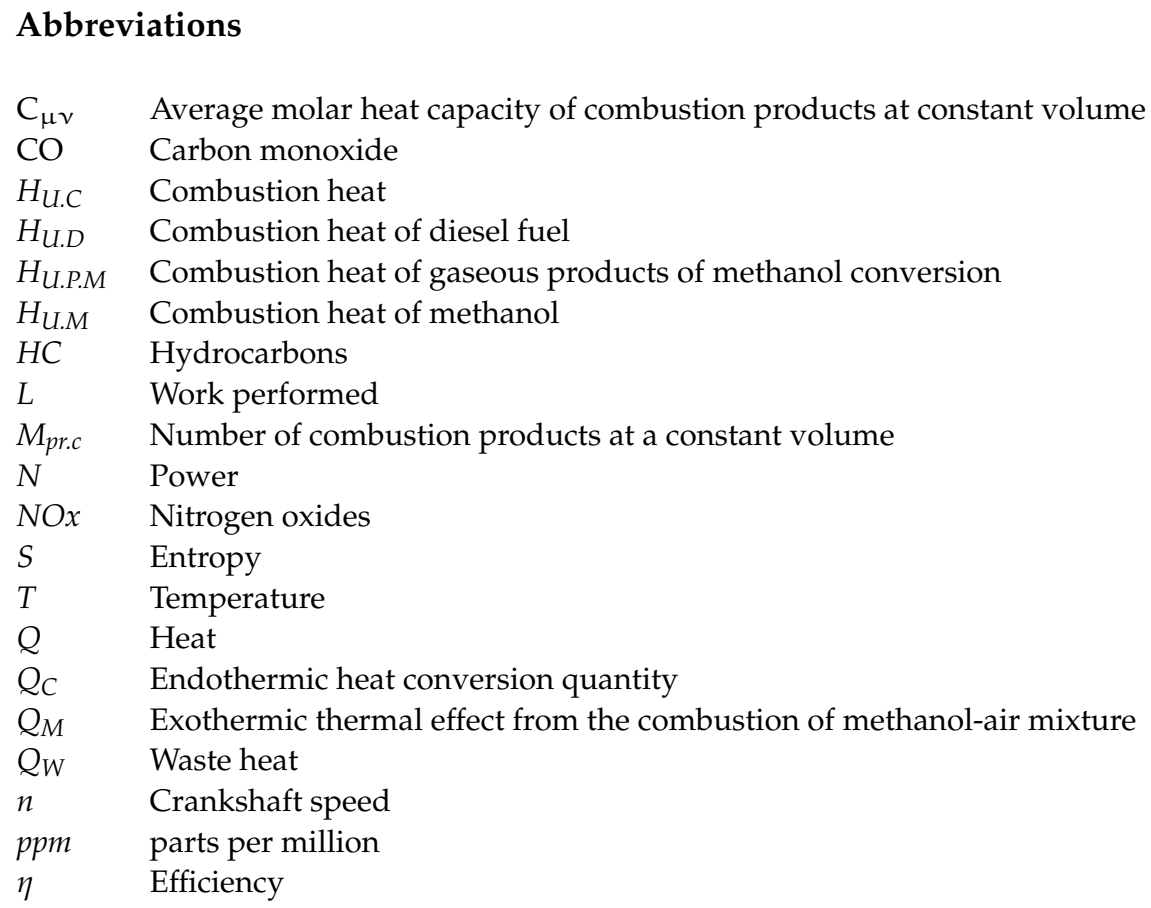

\section{References}

1. Panchuk, M.; Kryshtopa, S.; Sladkowski, A.; Panchuk, A.; Mandryk, I. Efficiency of production of motor biofuels for water and land transport. Nase More 2019, 66, 6-12. [CrossRef]

2. Kovalov, S. Designing the shape of the combustion chambers for gas engines converted on the basis of the diesel engines. East. Eur. J. Enterp. Technol. 2020, 2, 23-31. [CrossRef]

3. Panchuk, M.; Kryshtopa, S.; Sładkowski, A.; Panchuk, A. Environmental Aspects of the Production and Use of Biofuels in Transport. Lect. Notes Netw. Syst. 2020, 124, 115-168.

4. Vershina, G.; Bystrenkov, O. Influence of Diesel Fuel Ignition Portion Value on Working Process Parameters of Gas-Diesel Engine. Sci. Tech. 2019, 18, 395-400. [CrossRef]

5. Boretti, A. Advantages and Disadvantages of Diesel Single and Dual-Fuel Engines. Front. Mech. Eng. 2019, 5, 64. [CrossRef]

6. Jurkovič, M.; Kalina, T.; Jancosek, L.; Kadnar, R.; Gorzelanczyk, P.; Jerabek, K. Proposal of Conversion the Tugboat Engines to Diesel-LNG Operation. Adv. Sci. Technol. Res. J. 2019, 13, 129-142. [CrossRef]

7. Jovanović, S.; Knežević, M. Theoretical analysis of the cumulative costs of different diesel bus alternatives for a public transport in the city of Belgrade. Therm. Sci. 2017, 21, 669-681. [CrossRef]

8. Mateichyk, V.; Saga, M.; Smieszek, M.; Tsiuman, M.; Goridko, N.; Gritsuk, I.; Symonenko, R. Information and analytical system to monitor operating processes and environmental performance of vehicle propulsion systems. Iop Conf. Ser. Mater. Sci. Eng. 2020, 776, 012064. [CrossRef]

9. Zhanga, K.; Xin, Q.; Mu, Z.; Niu, Z.; Wanga, Z. Numerical simulation of diesel combustion based on n-heptane and toluene. Propuls. Power Res. 2019, 8, 121-127. [CrossRef]

10. Firmansyaha, A.; Aziz, A. Investigation of Auto-ignition of Several Single Fuels. MATEC Web of Conferences. 4th International Conference on Production. Energy Reliab. 2014, 13, 02013.

11. Kryshtopa, S.; Melnyk, V.; Dolishnii, B.; Zakhara, I.; Voitsekhivska, T. Improvement of the model of forecasting heavy metals of exhaust gases of motor vehicles in the soil. East. Eur. J. Enterp. Technol. 2019, 4, 1-8. [CrossRef]

12. Kryshtopa, S.; Kryshtopa, L.; Melnyk, V.; Prunko, I.; Demianchuk, Y. Experimental research on diesel engine working on a mixture of diesel fuel and fusel oils. Transp. Probl. 2017, 12, 53-63. [CrossRef]

13. Abbasi, S.; Bahrami, H.; Ghobadian, B.; Kiani, M.; Kiani, D. Energy Analysis of a Diesel Engine Using Diesel and Biodiesel from Waste Cooking Oil. J. Agric. Mach. 2018, 8, 149-157.

14. Afanas'ev, A.; Tret'yakov, A. Simulation of diesel engine energy conversion processes. J. Min. Inst. 2016, 222, 839-852.

15. Panchuk, M.; Kryshtopa, S.; Panchuk, A.; Mandryk, I.; Sladkowski, A. Perspectives for developing and using the torrefaction technology in Ukraine. Int. J. Energy A Clean Environ. 2019, 20, 113-134. [CrossRef] 
16. Abbondanza, M.; Cavina, N.; Corti, E.; Moro, D.; Ponti, F.; Ravaglioli, V. Development of a Combustion Delay Model in the Control of Innovative Combustions. E3S WEB Conf. 2020, 197, 6013. [CrossRef]

17. Cherednichenko, O. Efficiency Analysis of Methanol Usage for Marine Turbine Power Plant Operation Based on Waste Heat Chemical Regeneration. Probl. Energeticii Reg. 2019, 1, 102-111.

18. Tselischev, O.; Kudryavtsev, S.; Loriya, M.; Boychenko, S.; Lanetsky, V.; Matveeva, I.; Leonenko, S.; Tselishcheva, M. Modification of motor gasoline with bioethanol in the cavitation field. Vopr. Khimii I Khimicheskoi Tekhnologii 2020, 6, 171-178.

19. Bureika, G.; Matijošius, J.; Rimkus, A. Alternative Carbonless Fuels for Internal Combustion Engines of Vehicles. Lect. Notes Netw. Syst. 2020, 124, 1-49.

20. Korpaniuk, T.; Ishchenko, Y.; Koval, N. Backgrounds for improving resource management of agricultural enterprises based on economic diagnostics of biofuel consumption. J. Soc. Sci. Res. 2019, 5, 367-380. [CrossRef]

21. Bildirici, M.; Gökmenoğlu, S. Environmental pollution, hydropower energy consumption and economic growth: Evidence from G7 countries. Renew. Sustain. Energy Rev. 2016, 75, 68-85. [CrossRef]

22. Bahman, N.; Sina, F.; Shahaboddin, S.; Kwok-wing, C.; Timon, R. Application of ANNs, ANFIS and RSM to estimating and optimizing the parameters that affect the yield and cost of biodiesel production. Eng. Appl. Comput. Fluid Mech. 2018, 12, 611-624.

23. Havrysh, V.; Kalinichenko, A.; Minkova, O.; Lyashenko, S. Agricultural feedstock for solid and liquid biofuel production in Ukraine: Cluster analysis. Procedia Environ. Sci. Eng. Manag. 2019, 6, 649-658.

24. Plashikhin, S.; Zelenin, E.; Semenyuk, N.; Safyants, A. Purification of a flue gas from solid particles and acidic impurities. Int. J. Energy Clean Environ. 2019, 20, 247-259. [CrossRef]

25. Zhang, Z. Experimental Investigation on Regulated and Unregulated Emissions of a Diesel/ Methanol Compound Combustion Engine with and without Diesel Oxidation Catalyst. Sci. Total Environ. 2010, 408, 865-872. [CrossRef]

26. Li, Y. Numerical Study on the Combustion and Emission Characteristics of a Methanol/Diesel Reactivity Controlled Compression Ignition (RCCI) Engine. Appl. Energy 2013, 106, 184-197. [CrossRef]

27. Liu, Z. Economic Analysis of Methanol Production from Coal/Biomass Upgrading. Energy Sources Part B-Econ. Plan. Policy 2018, 13, 66-71. [CrossRef]

28. He, L.; Fu, Y.; Lidstrom, M. Quantifying Methane and Methanol Metabolism of “Methylotuvimicrobium buryatense" 5GB1C under Substrate Limitation. Msystems 2019, 4, 748-19. [CrossRef]

29. Liu, H.; Ma, J.; Tong, L.; Zheng, Z.; Yao, M. Investigation on the potential of high efficiency for internal combustion engines. Energies 2018, 11, 513.

30. Zhennan, H.; Sulong, G.; Xi, Z.; Shipei, X.; Ping, A.; Jiguang, C.; Jun, Y.; Feng, L.; Suyi, Z.; Miao, L.; et al. Reaction decoupling in thermochemical fuel conversion and technical progress based on decoupling using fluidized bed. Carbon Resour. Convers. 2018, $1,109-125$.

31. Mäyrä, O.; Leiviskä, K. Modeling in methanol synthesis. In Methanol; Elsevier: Amsterdam, The Netherlands, 2018 ; pp. 475-492.

32. Yakovlieva, A.; Boichenko, S. Energy Efficient Renewable Feedstock for Alternative Motor Fuels Production: Solutions for Ukraine. Stud. Syst. Decis. Control 2020, 298, 247-259.

33. Wargula, Ł.; Waluś Konrad, J.; Krawiec, P. The problems of measuring the temperature of the small engines (SI) on the example of a drive for non-road mobile machines. In Proceedings of the MATEC Web of Conferences, Rydzyna, Poland, 4-7 September 2018; Volume 254, pp. 4-7.

34. Marty, P.; Hétet, J.; Chalet, D.; Corrignan, P. Exergy Analysis of Complex Ship Energy Systems. Entropy 2016, 18, 127. [CrossRef]

35. Fernández-Yáñez, P.; Armas, O.; Gómez, A.; Gi, A. Developing Computational Fluid Dynamics (CFD) Models to Evaluate Available Energy in Exhaust Systems of Diesel Light-Duty Vehicles. Appl. Sci. 2017, 7, 590. [CrossRef]

36. Alarifi, A.; Alsobhi, S.; Elkamel, A.; Croiset, E. Multiobjective optimization of methanol synthesis loop from synthesis gas via a multibed adiabatic reactor with additional interstage CO2 quenching. Energy Fuels 2015, 29, 530-537. [CrossRef]

37. Tang, G.; Wang, S.; Zhang, L.; Shang, H. Diagnosis and Improvement of Combustion Characteristics of Methanol Miniature Reciprocating Piston Internal Combustion Engine. Micromachines 2020, 11, 96. [CrossRef] [PubMed]

38. Tartakovsky, L.; Baibikov, V.; Veinblat, M. Modeling Methanol Steam Reforming for Internal Combustion Engine. Energy Power 2014, 4, 50-56.

39. Korohodskyi, V.; Kryshtopa, S.; Migal, V.; Vasylenko, O.; Osetrov, O. Determining the characteristics for the rational adjusting of an fuel-air mixture composition in a two-stroke engine with internal mixture formation. East. Eur. J. Enterp. Technol. 2020, $2,39-52$.

40. Syed, K.; Gaddale, A.P.R. Conversion of diesel engine into spark ignition engine to work with cng and lpg fuels for meeting new emission norms. Therm. Sci. 2010, 14, 913-922.

41. Andersson, J.; Lundgren, J.; Marklund, M. Methanol production via pressurized entrained flow biomass gasification-Technoeconomic comparison of integrated vs. stand-alone production. Biomass Bioenergy 2014, 64, 256-268. [CrossRef]

42. Shamsul, N.S.; Kamarudin, S.K.; Rahman, N.A.; Kofli, N.T. An overview on the production of bio-methanol as potential renewable energy. Renew. Sustain. Energy Rev. 2014, 33, 578-588. [CrossRef]

43. Dalena, F.; Senatore, A.; Marino, A.; Gordano, A.; Basile, M.; Basile, A. Methanol production and applications: An overview. In Methanol; Elsevier: Amsterdam, The Netherlands, 2018; pp. 3-28. 